\title{
Aboriginal Land Rights in Australia: From the Mabo Decision to the Native Title Act 19931
}

\author{
By Hans Michael Kloth
}

This article deals with recent developments in situation of Australia's indigenous population, in particular with the impact of the Australian High Court's historic 1992 Mabo decision on Aboriginal land rights and the Labor govemment's Native Title Act 1993, introduced subsequently as a direct consequence of the court's ruling. After briefly surveying present trends in Aboriginal social, economic and cultural developments (I.), I will outline the legal position of Aboriginal Australians before Mabo (II.) and explain the backgound, core elements and some effects of the Mabo ruling (III.). Part IV contains an exposition of the central features of the Native Title Act 1993; the wider political implications of the Mabo debate are analysed in the concluding part (V.). I have rried to strike a fair balance between the presentation of the historical context, an exposition of the legal detail and political analysis in order to present the material, much of it hard to get by outside Australia, in a way pertinent to a broad range of interests.

\section{The Social, Economic and Cultural Situation of Australia's Aborigines in the $1990 \mathrm{~s}$}

Almost half way through the 1990s, the socio-economic situation of Australia's Aboriginal population continues to be as depressing as it has been in the past. 2 The mortality rate among Aboriginal Australians over all age groups is two-and-a-half times higher than that of European settlers; for men in the 35 to 44 age group it is eleven times as high. Average

1 I would like to thank Dr Michael Wooldridge MP, Deputy Leader of the Opposition, fonner Shadow Minister for Aboriginal Affairs, and his staff for their hospitality and help during a study visit in Canberra in November 1993. The material contained in this article was collected during that visit. I am further indebted to Dr Janet Gardiner of the Australian Embassy in Bonn for additional information. Brian Herron provided valuable comments. Any remainig errors are my responsibility alone.

2 The data in this section are taken from: I. Castles, Australia's Aboriginal and Torres Strait Islander Population. Census of Population and Housing, August 6, 1991, Australian Bureau of Statistics, Canberra, 1993; NJ. Thomson, "Recent Trends in Aboriginal Monality", in: The Medical Joumal of Australia, Vol. 154, February 18, 1991, p. 235 ff; H.Tesfaghiorghis / J.C. Altman, "Aboriginal Socio-Economic Status: Are There Any Evident Changes?", in: Centre for Aboriginal Economic Policy Research Discussion Paper, No. 3, 1991; A.H. Grey/ H. Tesfaghior ghis: "Social Indicators of the Aboriginal Population of Australia", in: CAEPR Discussion Paper, No. 18, 1991; Australian Institute of Health and Welf are. 
life expectancy for Aborigines is sixteen years below that of the average Australian. Only a third of Aboriginal men live to celebrate their sixty-fifth birthday. Twenty-eight times as many young Aborigines as could statistically be expected still die of infectious diseases. Alcoholism is endemic in Aboriginal reservations as well as among city-dwelling indigenous Australians. Infant mortality rates in 1988-90 were triple that of the Australian average.

Unemployment continues to be the scourge of Aboriginal existence. Significant parts of the Aboriginal population have no access to functioning labour markets as they live in remote and isolated parts of the Australian outback. Regardless of the oscillations of the economic cycle, Aboriginal employment rates have fallen continuously in the past two decades. While in 197160 per cent of Aboriginal males were employed, this figure had fallen to 40 per cent by 1986 . Despite the fact that only 43.4 per cent of indigenous Australians between 20 and 64 years of age participate in economic activity (i.e. have, or seek, employment), compared to 65.1 per cent for the whole of the Australian population, registered Aboriginal unemployment in 1991 was 30.6 per cent, three times the national average. In some remote rural areas of New South Wales, the figure exceeded 41 per cent. ${ }^{3}$ Of those Aborigines in work, 96 per cent are dependent employees. Of these, nearly half work in the public sector, predominantly in job creation-schemes (Community Employment Development Projects). To a significant extent these constitute hidden unemployment.

Average income of Aboriginal households is less than two-thirds of that of the average Australian household. At the same time, the financial burden placed on households by dependents is much greater for Aboriginal families: 73 per cent of Aboriginal households support dependents, compared to only 53 per cent of non-Aboriginal households. This tendency is aggravated by the fact that single-parent families account for 20 to 25 per cent of Aboriginal families in most states, while they make up only 6.8 per cent of non-Aboriginal ones.

Despite their enduring miserable socio-economic circumstances, Australia's Aborigines have since the 1970s increasingly de veloped a distinct cultural consciousness of their own. More and more, the white community, too, has become aware of the intrinsic value of unique indigenous cultural achievements dating back some 40,000 years. 4 Improved

3 These are conservative, census-based figures. The figures of the Commonwealth Employment Office are more than 30 per cent higher; cf. H. Tsfaghior ghis/J. C. Altman, p. 15.

4 The most important impulse for this developrnent was the so-called Franklin Dam Dispute of the early 1980s. This project would have destroyed Aboriginal cave paintings over 20.000 years old. The protests sparked not only the first ecological party in the world (the United Tasmania Group) but also created an awareness of the inherent value of indigenous cultural achievements among non-aboriginal and aboriginal Australians alike: During the blockade of the site, "the journey down the Franklin River became a pilgrimage for Aboriginal people to discover thir past"(Landmarks. 
Aboriginal self-organisation aided by the govemment and by growing outside support, particularly from the Australian arts scene, have helped to create an institutional basis for the demands of the Aboriginal people and to bring the issue of Aboriginal rights to the centre of public attention in Australia. 5 This development has been paralleled by the recognition of the deprivation of indigenous peoples in an intemational context. 6

\section{The Legal Position of Australia's Aborigines Before the Mabo Decision}

From the very beginning, the campaign for Aboriginal rights has - as in the case of indigenous peoples elsewhere - been inextricably linked with the question of land rights, challenging in fact the legality and validity of the European settlers' claim to the Australian landmass. The issue of land rights provided effective moral leverage and publicity, for instance when in 1988 Aboriginal leaders in traditional dress "landed" at Dover on occasion of the bicentenary of white settlement of Australia in 1988, planted the Aboriginal flag and proclaimed the annexation of the United Kingdom for the Aborigines of Australia. The land rights-issue also seemed to open a window of opportunity for the rapid improvement of the Aborigines' dire economic plight. Recognition of Aboriginal land claims would eventually enable them to reap some economic benefit from their property or at least obtain compensation for the factual loss of their land. More fundamentally, the land rights-issue

People, Land and Political Change, National Museum of Australia, 1993, p. 3). An interesting phenomenon is the fact that the statistical rise in the Aboriginal population between 1981 (159.000) and 1986 (227.600) cannot be explained by a natural increase. During this period, the willingness to identify oneself as of Aboriginal descent must have grown considerably. While some attribute this to a stronger Aboriginal sense of idenlity and self-assertiveness, ochers see it primarily as the effect of increased welfare payments under the post-1982 Labor govemment. Cf. WD. Borrie, "The Population", in: K. Hannock (ed.), Australian Society, Cambridge 1989, p. 132.

5 The Aboriginal and Torres Straits Islander Cornmission Act 1989 divided Australia into 36 regions for the pupose of Aboriginal self-administration, with triannually elected regional councils supported by the Aboriginal and Torres Straits Islander Cornmission (ATSIC). In the arts world, many intemationally renowned anists such as Australia's best-known rock group Midnight Oil supported the cause of the Aboriginals - see their 1987 world hit "The Dead Hear", a powerful enunciation of Aboriginal land rights.

6 The International Convention on the Elimination of All Forms of Discrimination was instrumental in deciding the Franklin Dam Dispute (cf. nose 3) in favour of the Aborigines. Moreover, the United Nations in 1982 officially reckognised that the issues pert aining to indigenous people could not effectively be subsumed under the headings of either minority rights (indigenous peoples are not necessarily minorities - e.g. in some South American countries) or racial discrimination (the aim of anti-discriminatory measures being equality, while indigenous people - in a special way require more "inequality"). The Working Group on Indigenous Populations has become one of the UN's most active fora, having - in view of the special problems of representation faced by many indigenous peoples - tacitly extended the right of participation in its deliberations to numeous indigenous representative bodies that do no fulfil the formal criteria. Cf. Douglas Sanders, "The UN Working Group on Indigenous Populations", Human Rights Quarterly, 11, 3, 1989, p. 406. 
was also rightly perceived by Aboriginal rights campaigners as the key to unlocking the whole system of bias against Aborigines, which had its roots in the legal mechanism through which the British had incorporated the Australian continent into their empire at the end of the 18 th century.

When James Cook landed in Botany Bay in $\mathbf{1 7 7 0}$ he decided that the level of civilisation of the natives he encountered did not make meaningful negotiations over cession of land possible. This assessment decided the future legal status of the indigenous population for worse, for it implied the legal classification of the Australian landmass as terra nullius, or uninhabited land, making all indigenous inhabitants subjects of the British crown. Consequently, British law alone pevailed in all legal relations, including those among Aborigines. Had Cook, who was in fact quite sympathetic towards the indigenous Australians and admired their - in the phrase of the day - "uncorrupted" way of life, negotiated with the tribesmen he encountered in even the most rudimentary fashion, the Aborigines' customary laws and traditions (including their concept of land title) would have prevailed as residual law at least in those areas in which the Crown did not explicitly legislate.?

For one thing, Cook's somewhat arbitrary classification meant the factual expropriation of the indigenous population. It also implied that native Australians would not be regarded by Australian law as as a distinct ethnic and cultural entity for 150 years. Before "the" law they were treated just as all other white, yellow, red, brown or black subjects of the British crown. Consequently, no means of arbitration in the event of conflict between Anglo-Saxon common law and traditional Aboriginal noms existed; enforcement of the law was therefore in fact synonymous with the subjugation of the Aboriginal population.8 Since even the regulation of inter-aboriginal affairs now became a matter for the British parliament (and later the Australian states and the Australian federation) traditional pattems of norm-setting and social regulation among Aborigines were eroded and often destroyed, contributing much to the breakdown of Aborginal society.

In the 1980s efforts were increasingly made to rectify the deficits of the past. In 1986 the Australian Law Reform Commission published a report recommending the incorporation of

7 According to Blackstone's classical commentary, "... if an uninhabited country be discovered and planted by British subjects, all the English laws are there immediately in force... But, in conquered or ceded countries, that have already laws of their own, the king may indeed alter or change those laws; but, until he does actually change thern, the ancient laws of the kingdom remain." (Sir William Blackstone, Commentary on the Laws of England, 1756, quoted from S. Maddock, "The Politics of 'Uninhabited' Land", in: B. Wright / D. Moady / L. Petchkovsky (eds.): Contemporary Issues in Aboriginal Studies, Vol. 2, Sydney 1988, p. 399.

8 Some examples in B. Ranfi-Panek, Anpassung und Konfrontation. Sozio-ökonomische Veränderungen und ihr Einfluß auf den Kulturwandel bei den australischen Aborigines, Bonn 1990, pp. 52 f. 
Aboriginal customary laws into the Australian legal system. However, the commission's report was largely ignored by the public, a fact which prompted sceptic comments on the likelihood of change in the foreseeable future. 9 After its 1987 general election victory Prime Minister Hawke's Labor govemment made a somewhat half-hearted attempt to address the question of reconciliation between indigenous Australians and European settlers in a basic document referred to as "Treaty", or "makaratta", but this approach was eventually abandoned. 10 It was therefore left to the courts to find ways to assess and redress the wrongs of the past; this in itself being indicative of the.willingness of white Australia to stand up to its history..

\section{Mabo and the Aftermath}

As early as 1982 indigenous islanders from the Murray Islands, located in the Torres Srait off the coast of the state of Queensland, had filed a lawsuit with the Australian High Court in Canberra demanding the recognition of their right to the possession of their native island of Mer (Murray). They argued that their ancestors had held legal title over the island before the annexation of the Murray islands by Queensland in 1879 and was hence unaffected by the annexation. 11 Neither had this title ever been formally extinguished by act of parliament.Iin the opinion of the Murray islanders, their title, base on their raditional laws and customs, thus still remained valid. This lawsuit, named the Mabo case after Eddie Mabo, one of the plaintiffs, thus represented a direct attack on the doctrine of terra nullius and, in a sense, on the raison d'état of the modem Australian state.

9 "The Recognition of Aboriginal Customary Laws", Australian Law Reform Commission 1986, Report 31; J. Crawford, "Australian Law after Two Centuries", in Hannock (ed.), op. cit., p. 194.

10 Cf. P. Kelly, The End of Cenainty. The Story of the 1980s, St. Leonards, N.S.W., Allen \& Unwin 1992, pp. 272, 362 f, 437. The "Treaty"-approach was thus abandoned at a time when the United Nation's Working Group on Inidgenous Peoples was embarking on a comprehensive study on the potential utility of "treaties, agreements and other constructive arrangements between inidgenous peoples and states". The working Group's final report, submitted to the Sub-Commission on Prevention of Discrimination and Protection of Minorities in 1993, stressed the value of such arrangements. The reaction of Aborigines to this failure was forcefully expressed in the song "Treaty" by the Aboriginal popgroup Yothu Yindi: "Well I heard it on the radio/ and I saw it on the television / Back in 1988 / All those politicians / Words are easy, words are cheap/Much cheaper than our priceless land / But promises can disappear / Just like writing in the sand" (Yothu Yindi: "Tribal Voice", Mushroom Records 1992).

11 At the time Queensland, now part of the Australian federation, was a separate British colony. 


\section{A "Judicial Revolution"}

On 3 June 1992 the Australian High Court ruled, with a 6 to 1 majority, that the Murray islanders had "native title to, and are entitled as against the whole world to the posession, occupation, and use and enjoyment of the lands of the Murray islands." 12 This truly historic ruling amounted to nothing less than a "judicial revolution" in Australial3, for its abandonment of the legal principle of terra nullius implied the ousting of the concept on which modern Australia had been founded and on which she had rested for more than 200 years.

The public's unease about this lost certainty was not alleviated by the strong words with which the court denounced the past treatment of indigenous Australians as a "conflagration of oppression and conflict which was... to spread actoss the continent [after 1788, H.M.K.] to disposess, degrade and devastate the Aboriginal people", who faced "deprivation of the religious, cultural and economic sustenance which the land provides" and were left as "intruders in their own homes". Australian law, Justice Brennan concluded, should not be "frozen in an era of racial discrimination"14.

Apart from this general insight, the court was tilted against terra nullius by the ability of the plaintiffs to provide valid and conclusive evidence in regard to two crucial aspects: First, they were able to demonstrate beyond reasonable doubt a continuous attachment to the land in question since before its annexation by Queensland in 1879. Second, the Murray islanders could prove that their community posessed a system of traditional laws and customs that included the notion of land ownership and predated annexation. Of probably decisive importance was a contemporary report by A. C. Haddon, a Cambridge anthropologist, who had visited the Murray islands twice in 1889 and 1898. Haddon had explicitly concluded that the annexation by Queensland had not made an impact on the islanders' traditional notion of property. 15 The factual basis upon which terra nullius rested had thus been exposed as a fallacy: the untested assumption that the indigenous population of Australia consisted merely of nomadic hunters and gatherers incapable of any "civilized" utterances. 16

12 Quoted in M. Mason, The Mabo Case - Native Title Ousts Terra Nullius, PRS Issues Brief, No. 9. 1992, p. 3.

13 M.A. Stephenson / S. Ratnapala (eds.), Mabo: A Judicial Revolution, Queensland University Press 1993.

14 These passages from the ruling were quoted by the Prime Minister, Paul Keating, when introducing the Native Title Bill 1993 for its second reading.

15 Landmarks, p. 4.

16 The point was also made in anoher song by Yothu Yindi: "This land was never given up / This land was never bought and sold / The planting of the Union Jack / never changed our law at all". 


\section{From Terra Nullius to Native Title}

The core of the Mabo decision was the replacement of the doctrine of terra nullius with the concept of native title, i.e. the acknowledgment of the existence of "some form" of Aboriginal land rights. This caused considerable disturbance in the (non-aboriginal) Australian public because the extent to which native title would warrant factual land claims by Aborigines remained completely unclear and Mabo was - maybe unsurprisingly - perceived primarily as a potential threat. Rumours circulated that countless average Australians now faced eviction from their own front lawn and that Aborigines would now claim the site of that national symbol of Australia, the Sydney Opera House.

Confusion, however, was by no means restricted to the general public. Constitutional lawyers and politicians alike were at a loss to foretell the implications of the Mabo decision on the Australian legal and political system alike. Although the concept of "native title" itself is well established in Anglo-Saxon common law17, its application leads to a number of practical difficulties.

Native title does not, for instance, encompass the unrestricted ownership contained in a freehold title. Rather, it involves "a continuation of the type of interests held in land before sovereignty was acquired by the (British) Crown"18, i.e. its extent is determined by the traditional laws and customs of the respective indigenous population. For this reason, native title may include a whole array of rights, such as right to posession of the land, right of access (e.g. to sacred sites), right to hunt, gather and fish on the property, use of the land for ceremonial purposes or the right to use the water flowing through or springing from the land. It may even include a right to the physical integrity of the land, thus implying a right to exclude mining. 19

Even the High Court Justices were not in agreement in regard to whether native title constituted a proprietary right conveying exclusive ownership of land or whether it merely had to be regarded as a personal, usufructuary right - a crucial difference, in particular with

17 In British common law, naturally imbued with feudalistic principles, ownership of land is derived from a legal title granted by the Crown, which, as sovereign of the land, is (and remains) holder of the ultimate, or "radical", title. Annexation of new territories is synonymous with the Crown's acquisition of sovereignty over these territories and hence it's acquisition of the radical title. In the case of the annexation of setled land, this does noc per se mean extinction of (native) title existing under the old law. In the case of unihabited land (or terra nullius), however, a native title, by definition, cannot exist and the Crown is free to grant secondary titles, freehold or leasehold, over whatever par of the new territory she pleases without first having to extinguish an existing native title.

18 Twomey, op. cit., p.5.

19 ibid., p. 6. 
respect to the important question of how native title might be extinguished. The court openly admitted that it saw no satisfactory and at the same time practicable way of incorporating native title into the system of Anglo-Saxon land law. Instead, the court accepted "the inappropriateness of forcing the native title to conform to traditional common law concepts", and suggested "to accept it as sui generis or unique". 20 However, three elements distinguish native title from other forms of land title:

- Native title may not be transferred to holders outside the circle of traditional holders without being extinguished (unless such transfer is possible under the applicable traditional laws and customs in the first place)

- Native title is a collective, not an individual title. It can only be claimed, and held by, a community of indigenous inhabitants.

- Native title can be extinguished by the Crown without right to compensation, if other laws are not contravened (e. g. the Racial Discrimination Act 1975 (Cth.), which in fact stipulates that compensation must be paid - see below)

\section{The Scope of the Mabo Decision}

Although the High Court's decision to overtum terra nullius in Mabo and others $v$. The State of Queensland [No. 2] initially met with an enthusiastic response from the Aboriginal community, some doubts lingered as to the relevance of Mabo to the Aborigines' cause.

One possible reservation derived from the fact that Torres Strait Islanders, to which the Murray islanders belong, are of Melanesian descent and ethnically quite distinct from the Aboriginals of the Australian mainland. Moreover, the fact that they inhabit islands made it relatively easy for Murray people to unambiguously define the territory they claimed and prove their continuous attachment to it. Third, it was sufficient for the Murray islanders to establish their continuous attachment to the land since 1879 (the year of the islands' annexation by Queensland) because their islands had not been claimed as part of Australia by the British Crown in 1788. Finally, the case of the Murray islanders seemed comparatively strong because their concept of property in many ways corresponded with European thinking (for instance land could be bequeathed or let).

For mainland Aboriginals, however, it appears much more difficult to conclusively prove their continuous attachment to a clearly specified area of land. The very nature of their

20 Mabo and Others v. The State of Queensland [No. 1], (1992), 175 Commonwealth Law Register 1, 89. 
habitat, the vast and deserted areas of central Australia, contravenes most efforts to fulfil the legal criteria set by common law and the court. To them, the vasmess of the land in most cases made the exact delineation of neighbouring territories superfluous. Moreover, the arid climate necessitated a certain degree of nomadic life. Mainland Aboriginals will also generally not be able to provide contemporary written evidence of their laws and customs, as was the case with the Murray islanders. As a consequence, they need to rely on oral history, which might be inadmissible before court as hearsay. In view of the fact that mainland Aboriginals would have to prove continuous attachment to the land back to 1788 (and not just 1879) in order to be able to claim native title, some commentators have concluded that even after the Mabo decision future Aboriginal land claims would not succeed in the courts. 21

These reservations were quashed, however, by the fact that the High Court explicitly stated - without being forced to do so by the facts of the case - that native title need not be extinguished on the Australian mainland. Justice Toohey wrote in his opinion that

"no basic distinction need be made, for the purpose of determinig what interests exist in ancestral lands of indigenous peoples of Australia, between the Meriam people [i.e. the Murray islanders, H.M.K.] and those who occupied and occupy the Australian mainland. The relevant principles are the same."22

It was this statement in particular, which prompted the Commonwealth govemment to introduce comprehensive legislation in order to pre-empt any Mabo-style claims on the Australian mainland.

\section{Mabo and Australian Federalism}

From very early on a key issue in the Aboriginal land rights-debate was the question of the states' rights vis-à-vis the Commonwealth and hence the future of Australian federalism. A constitutional predicament constitutes the basis for this conflict: while Land Law is a state issue (the states are holders of the radical title), race relations are the domain of the Commonwealth. Section 51 (xxvi) of the Australian constitution gives power to the Commonwealth Parliament to legislate with respect to the people of any race for whom it is deemed necessary to make special laws 23 , and under section 51 (xxix) the Federal Parliament has the power to make laws with respect to extemal affairs. (This latter provision was

21 G. Roberts, "Land Ruling has Little Effect: Goss", Sydney Moming Herald, 9.6.1992.

22 Quoced in Twomey, op. cit., p. 4.

23 The possibility of a clash between land law and civil rights had not occured to the authors of the Australian constitution, and until a referendum in 1967 Aboriginals were indeed explicitly excluded from section 51 (xxvi); cf. Twomey, op. cit., p. 21. 
used to incorporate the Intemational Convention on the Elimination of All Forms of Discrimination into Australian law in the Racial Discrimination Act 1975 (RDA), see below).

When the govemment of Queensland attempted to forestall an unwelcome outcome of the Mabo case by passing the Queensland Coast Declaratory Act 1985, which declared all titles held by Murray islanders retrospectively extinguished since the annexation of 1879 , this was overtumed by the Australian High Court in 1988 for being "inconsistent" with Section 10 of the Commonwealth's RDA and thus invalid under the Australian constitution (which in section 109 stipulates the precedence of federal over state law). The High Court, however, did not question the fundamental right of the states to legislate in the area of Land Law. The states therefore continue to be free in formulating legislation which does not contra vene Commonwealth laws and would thus eff ectively extinguish native title.

However, the Commonwealth may in tum use its "race power" to override any state legislation on native title. The decision of the Kealing government to introduce Commonwealth legislation to regulate Aboriginal land rights was thus interpreted by some conservativegovemed states (in particular mineral-rich Westem Australia, which is set to lose most from the government's Native Title Act) as a party-politically motivated attack by the Canberra Labor govemment on their constitutional rights. In view of the Federal Govemment's proposed legislation, which intended to validate native title to the greatest possible extent, the Westem Australian government in November 1993 introduced its own Land Rights (Titles and Traditional Usages) Bill (W.A.), which aimed to extinguish existing native title across the board and replace it with a mere statutory right to traditional use of land. The W.A. government declared its intention to take the Federal Government to the High Court on the issue of the states' right to legislate on land law. The Premier of Westem Australia, Richard Court, went so far as to raising the spectre of a break-up of the Australian Commonwealth, only just stopping short of publicly considering secession. 24

\section{The Native Title Act 1993}

The Keating govemment's motives for following up the High Court's historic decision with such major, complex and politically polarizing piece of legislation are numerous and not all are easily disentangled from the traditional mêlee that is Australian politics. Without doubt, the spectre of successful Mabo-style claims on the Australian mainland raised by the wording of the Mabo ruling required some legislative answer - from a government point of

$24 \mathrm{Mr}$ Cour said that "if (the Federal Govermment) is continually going to erode the position of the states, the end result of that is the Federation splits up", M. Coffey, "WA wams of split over Mabo", Sydney Moming Herald (Sunday edition), 14.11.1993. 
view, the court had created a major problem, not solved one. Nonetheless it was neither a forgone conclusion that Mabo would be an issue for the Federal executive rather than the State governments to act upon, nor that a less ambitious and comprehensive approach would be in appropriate.

But there did seem to be an intrinsic political necessity for the Labor party to finally steer its much flaunted but long stalled policy of reconciliation with Aboriginal Australia toward some presentable result in order not damage the party's credibility in social justice issues. Also, the political cost of pushing through such potentially divisive legislation numed out to be relatively small as long as the opposition, transfixed on the bill's supposed "unworkability" and deadlocked in a "pro-industry" position which was perceived by the public as dogmatic, "cold" and not always free of "racist" undertones, could be effectively countered with florid rhetoric about the humane objectives of the legislation, thus by and large avoiding debate of its practical weaknesses. 1993 had been declared the "International Year of the World's Indigenous People" by the United Nations (slogan: "A New Partnership"), and the Mabo decision therefore provided a well-timed opportunity to demonstrate Australia's commitment to intemational human rights standards to the outside world and to highlight the govemment's international standing at home, the bill being a sure success with the relevant intemational bodies. It probably is a fair guess that the Keating government also perceived Mabo as an opportunity to tighten its grip on the states, most of them governed by the federal opposition. The tactical beauty of the situation was that the international context of the issue not only provided the welcome opportunity for a potential public relations scoop but in fact the means to realize domestic goals: By construing the Native Title Act 1993 as a "special measure" for the benefit of Aboriginals under Article 1(4) of the International Convention on the Elimination of All Forms of Discrimination and section 8 of the RDA, the statutory regulation of native title fell under the category of antidiscrimination legislation rather than land law, thereby establishing Commonwealth and avoiding State jurisdiction.

\section{Validation}

In view of the High Court's affirmation of the continued existence of native title, the Native Title Act 1993 seeks to recognise and protect such itles as far as possible. Section 223 of the Act defines native title as "the rights and interests in land and waters that Aboriginal and Torres Strait Islander peoples have under their traditional laws and customs and that are recognised by common law".25 Individual native titles are to be recognized through a

25 The information in the following section is taken from Native Title Bill 1993, Explanatory Memorandum, Part A; Bills Digest No. B. 63: Native Title Bill 1993; The Hon. Paul Keating, Second Reading Speech, Native Title Bill 1993; "Highlights of the Native Title Bill 1993 (government 
process in which holders of interests in land may apply for a determination as to the existence or otherwise of native title (sections 13,61,225). In order to facilitate land management, native title claims and determinations are to be collected in two public registers, the Register of Native Title Claims (Part 7 of the Act) and the National Native Title Register (Part 8).

While recognition is one thing, protection of native titles is another. The Act stipulates that land grants made after 1 January 1994 will not extinguish naive title, the so-called "nonextinguishment principle" (section 238). In the case of conflict between past grants and native title the grants will prevail until they expire, after which native title will again have full effect. (The non-extinguishment principle will not apply when title holders choose to give up their native title (section 21) or the land is acquired by the government under compulsatory acquisition legislation (section 23(3)b)). The Act provides a legal mechanism to validate past Commonwealth and State acts (clauses 13 and 18), i.e. to make them "nondiscriminatory" in line with the norms of the RDA, which will take precedence over the Native Title Act (section 7).

The effect of validation on native title depends upon the category in which the specific interest is classed according to the Native Title Act (see also chart 1):

- Category A past acts (sections 15(1)(a) and (b) and 229) include grants of freehold interests or of a commercial, agricultural, pastoral or residential lease (section 246 to 249 ), or the construction of a public work (section 253). Only in the case of such interests will the validation of a past act or grant extinguish native title.

- Category B past acts (sections 15(1)(c) and 230) includes grants of other leasehold interests not covered by category $A$ (except mining leases). For category B past acts, the validation will only extinguish native title to the extent of any inconsistency between two sets of rights and interests.

- Category C and D past acts (sections 15(1)(d), 231 and 232) cover mining leases (category C) and all other grants by the Commonwealth such as licences and permits etc. (e.g. for fishing or hunting - category D). If validated by the Commonwealth or by the states (pursuant to Commonwealth legislation), mining leases will not extinguish native title, but native title is subject to the lease for the term of the lease and any legitimate renewal. Licences, permits etc. will not extinguish any native title, such titles will be subject to the non-extinguishment principle of section 223 .

press release); Native Title, Attomey General's Department, Australian Govemment Publishing Service, Canberra 1994. 


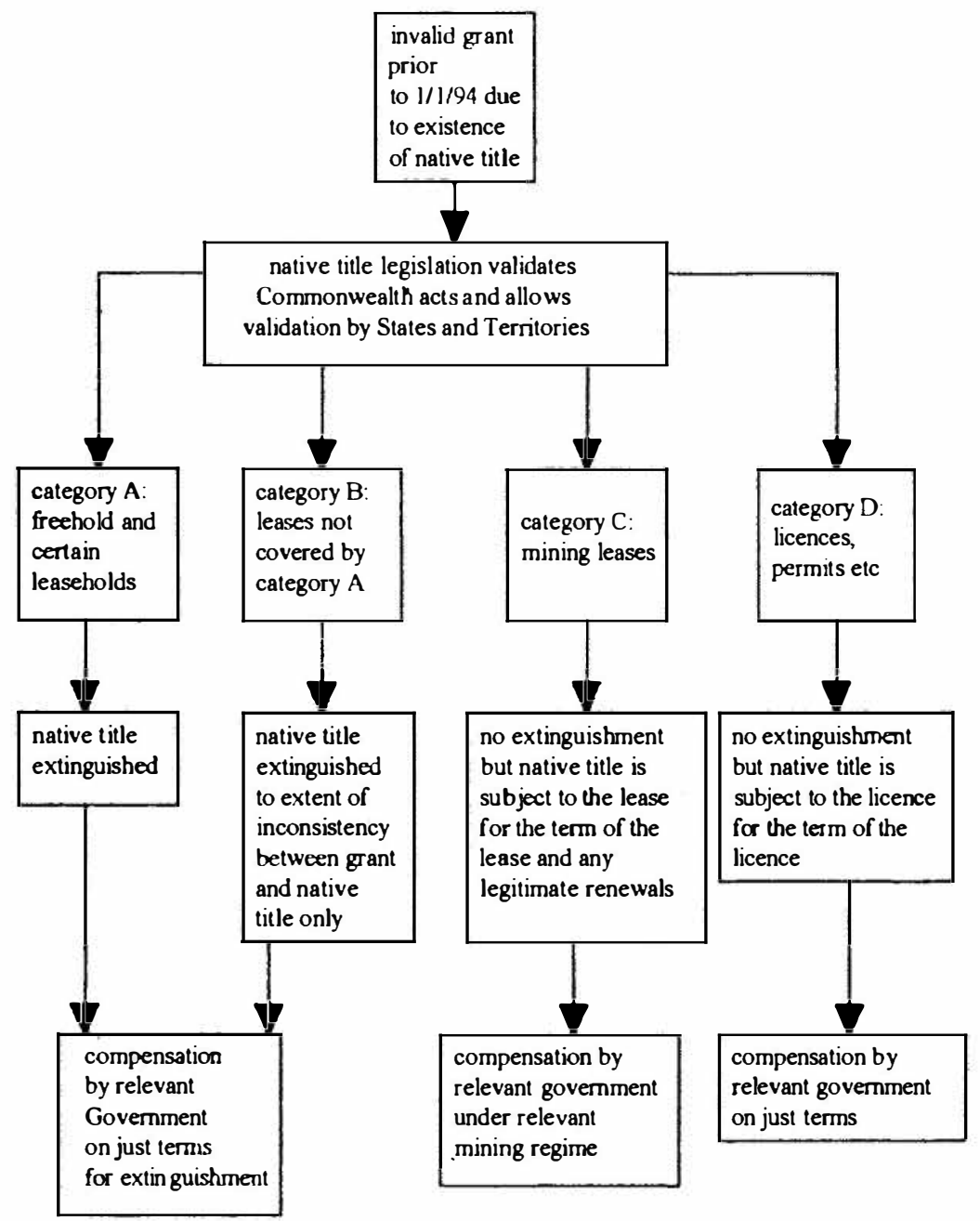

Chart 1: Validation of past grants affecting native title

The Native Title Act 1993 stipulates that future acts over native title land can only be done if it is a "permissible future act" (defined in section 235). A future act over native title land is permissible if it were permitted over "ordinary title land" (meaning generally freehold land) and affects native title holders in the same way that it would affect ordinary title holders, or puts native title holders in the same position as ordinary title holders (section 


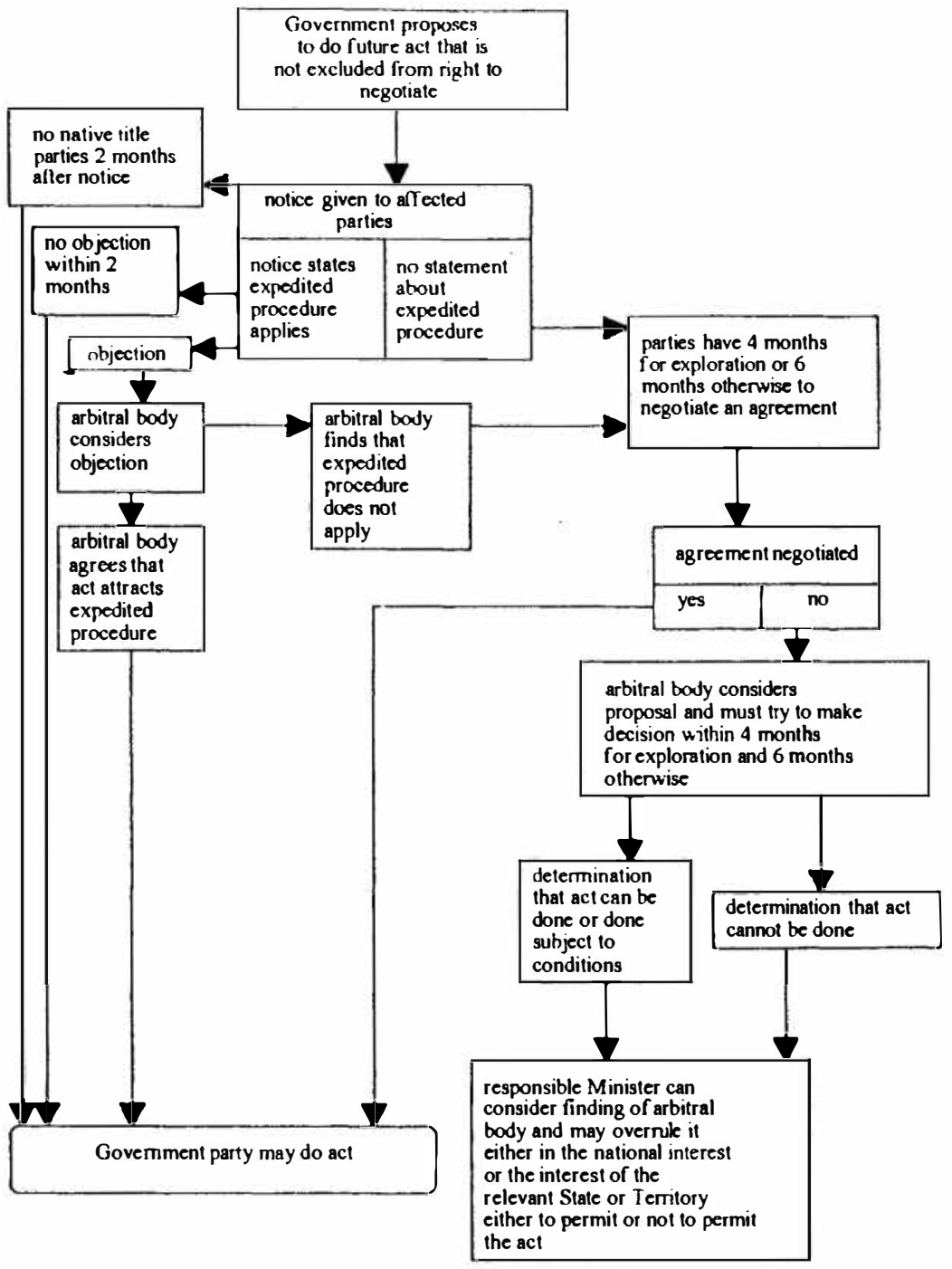

Chart 2: Future acts and native tit le - right to negotiate where native title is known

235(5)). An example for a permissible future act is the grant of a mining interest. Such grants can be made over freehold land, so they can be made over native title land as well. Other future permissible acts are those carried out under Compulsory Acqusitions Acts. In 
effect, native title will thus only be able to be extinguished by agreement with native title holders or under through compulsory acquisition. There is also an important distinction between "offshore" and "onshore" places: while future acts pertainig to onshore places are permissible only with regard to the relevant qualifications listed above, future acts in off shore places are permissible without qualifications and can be done even if that place is subject to native title (section 235(8)) - an important qualification in view of the future exploitation of submarine ressources. The criteria for "permissible future acts" must be met by legislation from 1 July 1993 and as of 1 January 1994 by all other acts and grants.

\section{Arbitration}

The principle of arbitration is the guiding idea behind the Federal Government's Mabo legislation.26 Over and above the procedural rights of ordinary title holders, registered native title holders and registered claimants will - "in recognition of the special attachment that Aboriginal people and Torres Strait Islanders have to their land" - be given special rights of negotiation with respect to some permissible future acts (compare Subdivision B of Division 3 of Part 2 of the Act). The right to negotiate is forfeited, however, if no native title holder or registered claimant makes himself known within two months of notification of the proposed act (sections 28(1)(a) and 30).

The right to negotiate does not constitute a right to veto or re ject permissible future acts, however. If the parties cannot reach agreement, either side may apply to an arbitral body for a determination of whether the act may go ahead and if so on what conditions (sections 27 and 35). The arbitral body has to take account of the impact of the proposed act on the way of life, culture and traditions of the native title holders on the one hand and the economic significance of the proposed act to Australia and the State or Territory on the other (section 39). The determinations of the arbitral body may be overruled by the relevant State, Territory or Commonwealth Minister where this is in the State, Territory or national interest respectively (section $42(1)$ to (3)).

26 In this respect the Native Title Act 1993 seeks to implement the standards contained in the draft Declaration on Indigenous Peoples' Rights which is being developed by the United Nations Economic and Social Council's Working Group on Indigenous Populations. Cf. Elsa Stamatopoulou, "Indigenous Peoples and the United Nations: Human Rights as a Developing Dynamic", Human Rights Quarterly, 15, 1, 1994, pp. 59-81, p. 73 ff; see also the initial 1988 draft submitted by the Greek jurist and former chairperson of the Working Group, Erica-Irene Daes (Appendix to Douglas Sanders, "The UN Working Group on Indigenous Populations", loc. cit., pp. 406-433. For general information also "The Rights of Indigenous Peoples", UN Centre for Human Rights, Fact Sheet No. 9. 


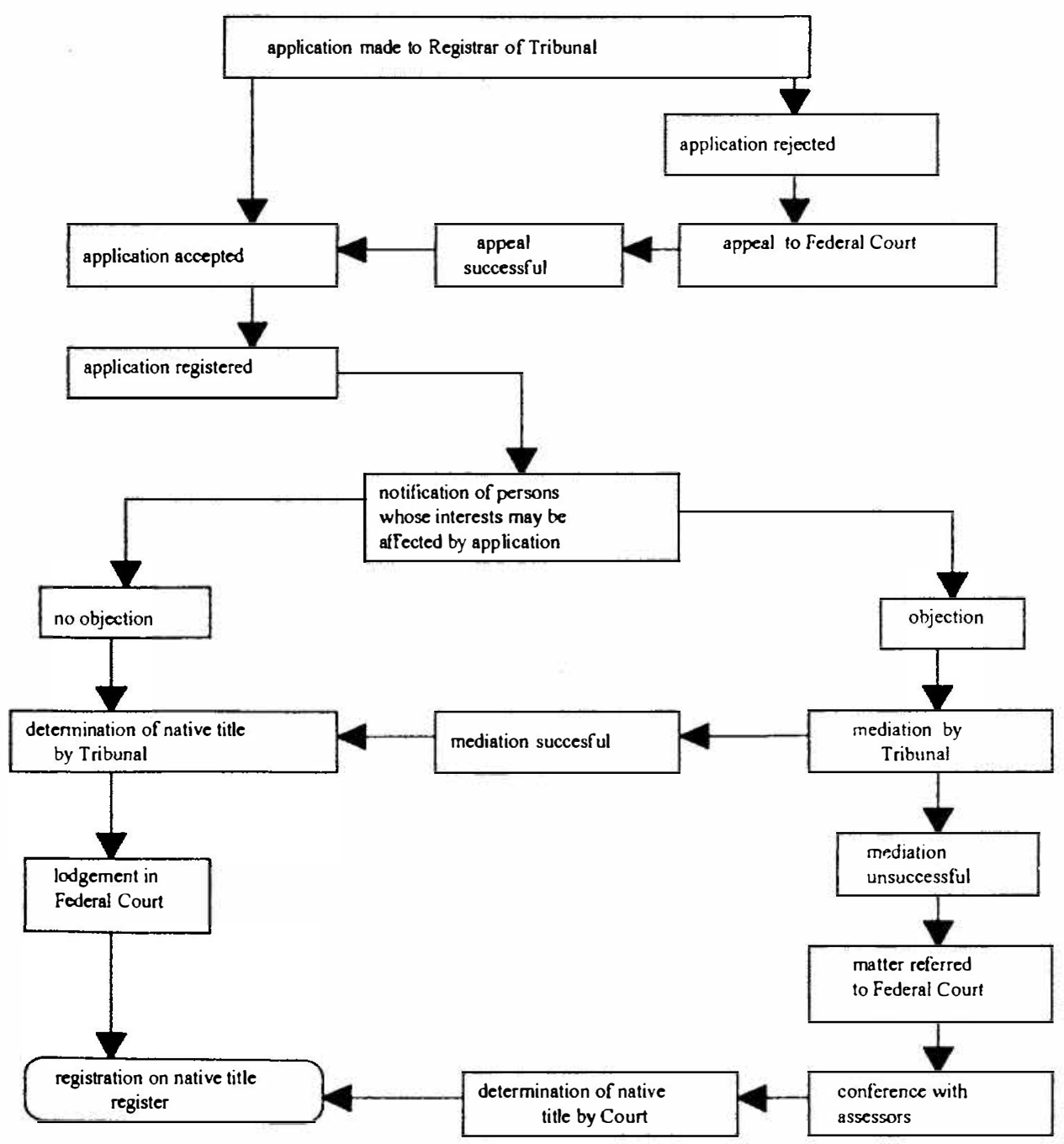

Chart 3: Claim for determination of native title by National Native Title Tribunal (NNTT) 
Existing State or Territory bodies will serve as arbitral bodies if they comply with the criteria set by the Act and have been recogrised by the Commonwealth Minister responsible (sections 27 and 251). There will thus be no strict necessity for the Commonwealth to impose its arbitral system where a State or Territory system dealing with grants exists which gives native title holders a right to negotiate equivalent to that granted under the Native Title Act 1993. For the remainder of the arbitration cases, the Act proposes to set up a National Native Title Tribunal (NNTT). The NNTT will also deal with uncontested claims to native title and for compensation conceming the Commonwealth, and it will be able to inquire into any issue in relation to native title referred to it by the Commonwealth minister. Contested claims for a determination of native title or for compensation will come before the Federal Court, which is given jurisdiction in native title matters (part 6 of the Act).

\section{Compensation}

It is important to note that in Aboriginal customary law land could not be bought and sold. As a consequence, native title cannot be up given up except to the Crown. The possibilities for holders of native title to realize the value of their land is therefore restricted to compensation arrangements with the State or Commonwealth govemments, unless they give up their native title in exchange for a common statutory (e.g. freehold or leasehold) title (section 21(1)(a)). Such a statutory itle would be tradeable, but the special rights of native title holders would, of course, be forfeited. 27

Under the Native Title Act 1993, Aboriginal native title holders will be eligible for compensation on "just terms" by the relevant (State or Federal) govemment where their title is extinguished through validation of a past grant (sections 17, 20 and 51). Where it is merely impaired, for instance by the validation of an existing mining lease (i.e. category $C$ past acts), compensation will be paid to native title holders where freeholders would have received it and will be assessed in the same way as for freeholders.

The Commonwealth may provide compensation even for the effect of State and Territory validations, although generally compensation will have to be provided by the states for their actions and by the Commonwealth for Commonwealth actions. If a State refuses payment of compensation, a native title holder may follow up his claim to compensation against the Commonwealth govemment in the NNTT and the Federal Court (see above). Native title holders may also claim non-monetary compensation, including other property or the provision of goods and services (sections 51(6) and 79).

27 This was the approach of the legislation introduced by the Liberal (i.e. conservative) govemment of Westem Australia in defiance of the proposed Commonwealth Bill, see above (II.4). 


\section{Conciusion: Criticisms and Perspectives}

\section{Criticisms of the Native Title Act 1993}

Criticism of the the Native Title Bill and Act has been widespread and harsh from the very beginning. Despite the fact that the Labor government took nine months to work out its details, consulting closely with the representative bodies of the Aboriginal and Torres Strait Islander communities, the opposition immediately denounced the proposed bill as "a constitutional nightmare", "unworkable" and "a lawyers' picnic". Deliberations of the bill in the Senate, where the Labor government depends on votes from the Green Party and the Australian Democrats, lasted for more than seventy hours before the prime minister personally struck a deal with the Greens which ensured passage of the bill and enabled the government to guilliotine debate. In all, more than one hundred amendments were proposed. The Opposition made a point of rejecling all amendments regardless of content, even those considered to be "pro-industry". In the words of the Leader of the Opposition, Dr John Hewson, "this is disastrous legislation, it can't be improved"28. Hewson argued that the Act infringes upon fundamental rights of the States and that the creation of at least three new bureaucracies (the NNTT, the Native Title Registrar and the Land Fund) will be inefficient, unnecessary and indicative of the govemment's "jobs for the boys"-policy.

The opposition's unreserved disapproval has been echoed by the farmers' lobby and by the mining industry in particular, who fear protracted, difficult and costly negotiations with native title holders under the new regime. Nevertheless, representatives of the National Farmers' Federation (NFF) eventually gave cautious support to the legislation, since the inclusion of pastoral leases in category $\mathbf{A}$ past acts gave them "a reasonable degree of certainty that there would be very little change in relation to their current land tenure" 29 . Mining leases, however, will be subject to the non-extinguishment principle, and the Australian Mining Industry Council (AMIC) persistently resisted the bill, calling it "a confused mess" 30 .

\section{Some Perspectives on the Future}

However, in the absence of a new regime Mabo-style claims would inevitably result in costly, year-long legal battles that would foster a spirit not of reconciliation but of even more bitterness between Aboriginal and non-Aboriginal Australians. This cannot be in the

Sydney Moming Herald, 22.12.1993, p. 1. This strategy alienated pro-industry National Party Senators, however, who crossed the fioor on a number of votes, effecrively splitting the opposition.

30 Lauhlan McIntosh, execurive director of AMIC, ibid. 
interest of any party, and some first steps have been taken towards practical co-operation. The AMIC and the Council and Chamber of Mines and Energy have initiated a programme aimed at fostering better relations between miners and Aboriginal communities. The first post-Mabo agreement between traditional owners and miners was concluded in Katherine (Northem Territory) in October 1993, where mining rights at the Mount Todd gold mine were granted by the Aboriginal native title holders in retum for improved infrastructure and jobs: already, one quarter of all jobs are filled by Aborigines, upcoming positions are first offered to native Australians. Workers are obliged to participate in a "cross-cultural training exercise". More agreements of this kind are being negotiated, giving rise to hopes of more voluntary co-operation and hence less need for state regulation. 31

With implementation of the Native Title Act still in its infant stages, it is not yet clear whether the good intentions of the Act will translate into a palpable improvement of the lot of the majority of Australia's Aborigines. For one thing, the implementation will require the cooperation of the States. Even discounting the possibility of the States initiating High Court action, the withholding of cooperation by the States would necessitate the introduction of a whole new federal administrative system to handle native title. The Federal Court's resources will already be stretched to the limit if the new regime functions as set out in the Act.32 An optimistic, albeit somewhat cynical prognosis might thus conclude that the best possible outcome would be for the Act to stimulate voluntary co-operation of the kind described above for sheer fear of massive bureaucratic interference.

As a next step, the government will have to present the comprehensive social justice package it has promised to Aborigines. The National Aboriginal and Torres Straits Islanders Land Fund provided for in the Act (section 201) and inaugurated on 1 July 1994 is the starting point for this project. It is intended to help disposessed Aborigines who do not benefit from the Native Title Act to buy land and manage it "in a way that provides economic, environmental, social or cultural benefits to them". In many ways, the land fund and the social justice package will be more important to the vast majority of Aboriginal Australians than the Native Title Act which, after all, deals mainly with the legal nittygritty of land title validation. The Keating government has promised that Aborigines will be consulted extensively in the drafting process and has announced plans for a "National Reconciliation Conference" later in 1994 to "look at ways of increasing the participation of indigenous people in the nation's economic life and saf eguard their culture."33

A number of more general conclusions transcending the wrangle over legal detail, shortterm political advantage and economic benefit emerge from the Mabo debate. At a time

31 The Bulletin, 2.11.1993, p. $16 \mathrm{f}$.

32 "Onus is now on the Liberal Party politically", Canberra Times, 24.12.1993.

33 Sydney Moming Herald, 17.11.1993. 
when external developments, economic insecurity and a loss of old certainties in general are already forcing a review and - possibly - redefinition of the Australian national identity, the High Court's decision represents a severe challenge to the Australian self from within. At the threshold to the third millenium Australia is facing the difficult task of coming to terms with its relative economic decline vis-à-vis the neighbouring "tiger" states, the worst recession since the 1930s and the foreseeable end of the social, economic and cultural monopoly of the Old World settlers through Asian immigration. Prime Minister Keating is determined to abolish the still powerful symbol of the Queen as head of state and wants to make Australia a republic by the year 2000 . He has already called Australia "an Asian country", expressing as much the facts of geography as the necessity to redirect Australia's trade flows. Nevertheless, this was a bold remark in a country that officially pursued a "White Australia" policy until the early 1970s.

Where does this leave Australia's Aborigines? Mabo has undoubtedly boosted most Aborigines' sense of identity, possibly even given some a sense of purpose. But socially, economically and politically they are still weak and will remain weak for a long time to come. True, the Native Title Act and the social justice package (when, and if, it comes) offer Aborigines prospects undreamed of twenty or even ten years ago.Too many of them, however, will first have to be put in a position to leam how to grasp these opportunities. This process alone might well take a generation or two. Last but not least, Aboriginal politics is as much dominated by vested interests and beset by politicking and in-fighting as white politics. 34 General experience suggests that the sudden influx of big money and the creation of new buraucracies will usually not help to eradicate such phenomena.

For the present, much of the answer therefore depends on how non-Aboriginal Australians will interpret the end of the doctrine of terra nullius. Will they regard it as a natural and overdue step towards a necessary redefinition of what "Australia" means, and undertake a collective effort to empower Aborigines to take their due place in Australian society? Or will those who already feel "encircled" by "aliens" succumb to some kind of "stab in the back"-mentality that could split Australian society? In order to overcome the divisive potential contained in the issues surrounding Mabo it will also be necessary for the Federal Government and the States to find a compromise which safeguards the States' rights and minimizes bureaucratic intervention on the one hand while not leaving any loopholes for a continued tacit discrimination of Aborigines under the pretext of states' sovereignty. For the Federal govemment and the States (even some States) to engage in protracted "constitutional warfare" cannot be the way forward in an issue as important as this.

34 See for instance "Black negotiators 'gave away' fundamental rights", The Australian, 12.11.1993, p. 6. 
But maybe one should be careful not to overemphazise the many insecurities that presently beset Australia. Australians still have many positive things to look to. Theirs is a rich country in terms of both natural and human resources. Its colonial heritage comprises many aspects well worth preserving, not least a functioning parliamentary democracy - a positive feature not shared by many neighbouring states. The Australian approach of the "Fair Go" has great integrative potential and now only needs to be extended to native Australians.

In any case, the date by which progress will have to be evident has already been set: In little more than five years the eyes of the whole world will be on Australia when the Olympic summer games will be held in Sydney. But that - if it is not inappropriate to quote Rudyard Kipling, the avowed imperialist, in this context - is a different story. 


\section{Aboriginal Land Rights in Australia: From the Mabo Decision to the Native Title Act 1993}

\section{By Hans Michael Kloth}

The most recent data on social, economic and cultural rends regarding Aboriginal Australians show that while cultural self-awareness among Aboriginal Australians is growing, little to no progress has been achieved in regard to improving the socio-economic base of Aboriginal existence. Much of the blame for the deprivation of Aborigines has been attributed to their legal position and to the problem of land rights, rooted in the ancient common law principle of terra nullius, in particular. In a seminal decision, the Australian High Court in June 1992 overthrew terra nullius in the so-called Mabo case, replacing it with the concept of "native title": Aboriginal Australians are now in principle "entitled as against the whole world to the posession, occupation, and use and enjoyment" of their ancestral lands. The article outlines the legal position of Aboriginal Australians before Mabo and explains background, core elements and some effects of the Mabo ruling, arguing that it constitutes in effect an attack on the identity of modem Australia. The Mabo decision and in particular the Labor government's introduction in November 1993 of comprehensive native title legislation spurred one of the greatest public controversies of recent times. The Native Title Act 1993 was eventually enacted against the fiercest opposition from the Liberal/National parties, parts of business and a number of States. The central features of the Act are outlined in the article, which concludes with an assessment of the wider political implications of the Mabo debate. 